\title{
LICHENS IN AREA OF METEOROLOGICAL AND RADAR STATION KOJŠOVSKÁ HOL'A (VOLOVEC MOUNTAINS, SE SLOVAKIA)
}

\author{
M. GogA*, D. Ručová and M. Marcinčinová \\ Department of Botany, Pavol Jozef Šafárik University, Mánesova 23, 04001 Košice, Slovakia; \\ E-mail: *michal.goga@upjs.sk
}

(Received 17 November, 2017; Accepted 31 December, 2017)

The Volovec Mts (Volovské vrchy) have insufficiently been investigated area for lichens. Kojšovská hol'a is one of the highest parts in the Volovec Mts. No records of lichens were published from here. Some historical collections need revision. The list of 35 lichen species collected by the authors is presented from the investigated areas. Three interesting and vulnerable lichens are characterised in more details: Cladonia ciliata var. tenuis, Cladonia cornuta and Umbilicaria vellea. The area of Kojšovská hol'a gives further opportunities for new findings.

Key words: biodiversity, Slovak Ore Mts, Volovec Mts

\section{INTRODUCTION}

According to the regional geomorphological classification (Miklós 2002), the studied area around the meteorological and radar station at Kojšovská hol'a is a part of the Slovenské rudohorie (Slovak Ore Mts), including the region Volovec Mts (Volovské vrchy), and a subdivision Kojšovská hol'a. According to the regional geological division of the Western Carpathians (Vass et al. 1988), the area is located in the Slovak Spiš and Gemer region (Spišskogemerské rudohorie). Quaternary and gemerial sediments are involved in the geological structure of the area. Kojšovská hol'a is included in the documentation of the land plan of the Košice Region under the Volovec Mts, as a supraregional tourist centre Zlatá Idka - Kojšovská hol’a. Kojšovská hol'a is one of the oldest sport centres near Košice. In the 1940s, the Erika cottage was built. The climatic station of the Slovak Hydrometeorological Institute is situated at an altitude of $1243 \mathrm{~m}$ a.s.l., and as a terminated observation station operated from 1st January 1989 to 31st May 2007. At present, only the radar workplace is located on Kojšovská hola. The following characteristics were observed at the station: air temperature by stationary thermometer in three observation periods and thermograph, maximum and minimum air temperature, air humidity, wind direction and wind speed, rainfall, winter snow cover height. Based on the climatic breakdown of Slovakia (Miklós 2002), the lower part of the territory (Zlatá Idka $635 \mathrm{~m}$ a.s.l.) is in a slightly warm climatic area and at 
higher elevations (Kojšovská hol'a $1245.7 \mathrm{~m}$ a.s.l.) it is in a slightly cold area. The average air temperature during the winter months (from December to March) reaches $-4.7^{\circ} \mathrm{C}$ on the top parts of Kojšovská hol'a. In this area it is possible to identify acidic soils (Zlatá Idka) to severely acidic ones (the ridge area itself). According to the phytogeographical division of Slovakia (Futák et al. 1966), the investigated area belongs to the Western Carpathian flora region (Carpaticum occidentale), and the area of the Carpathian flora region (Praecarpaticum). These consists of large areas of grasslands with the character of the mountain meadows. A large part of the area has disturbed vegetation. It was damaged due to the construction of the meteorological station and recreational facilities. Our study reveals the currently known species as a reference for further monitoring of human impact and climatic changes. Despite their size, there is the lack of information about the lichen flora in the Volovec Mts. The first lichen records from this area were published by Hazslinszky (1859), who recorded 15 Lecanoraceae species, i.e. Pannaria microphylla, Amphiloma elegans, Placodium circinatum, Candelaria vulgaris, Lecania fuscella, Rinodina metabolica, Callopisma cerinum, Lecanora badia, Ochrolechia pallescens, Icmadophila aeruginosa, Acarospora cervina, Aspicilia gibbosa, Urceolaria scruposa, Phialopsis rubra and Gyalecta cupularis, as well as 15 Lecideaceae species, i.e. Psora lurida, Thalloidima candidum, Bacidia sp., Biatorina pineti, Biatora vernalis, Bilimbia faginea, Abrothallus smithii, Celidium stictarum, Diplotomma alboatrum, Buellia dubyana, Lecidella sabuletorum, Lecidea albocoerulescens, Rhizocarpum geminatum, Sarcogyne pruinosa, and Arthrosporum accline. Later lichens were collected and identified by lichenologists F. Fóriss, J. Hruby, A. Lackovičová, E. Lisická, I. Piśút, J. Suza and A. Vězda (Orthová 2003). There is only one whole work about the Volovec Mts by the Moravian lichenologist J. Suza (Suza 1949). He identified lichens from seven localities: Folkmarská skala, Kurtova skala, Vápenica pri Margecanoch, Poráčska dolina, serpentínový ostrov pri Jaklovciach, Štós and Gelnica, but lichens from one of the highest parts of the Volovec Mts, Kojšovská hola, were not recorded. This interesting area gives opportunity to lichenologists to find interesting species or new floristical records similarly to Lisická-Jelínková (1974). She found the boreal lichen Parmelia incurva near the village Drnava. The lichen flora of this area was studied further by P. Mráz in 1994-1997 (Orthová 2003). During this period, he collected a great amount of lichen material of various species (unpublished).

\section{MATERIAL AND METHODS}

The lichen material was collected in October 2017 during field research at Kojšovská hol'a. The localities, where lichen material was collected and determined are marked by numbers from 1 to 6 on the map. The geographical coordinates were taken from Garmin eTrex 20 in the WGS-84 coordinate system. 
The map was produced in ESRI ArcMap version 10.2.2.3552 (2014), sources for World Imagery basemap: Esri, DigitalGlobe, GeoEye, i-cubed, USDA FSA, USGS, AEX, Getmapping, Aerogrid, IGN, IGP, swisstopo, and the GIS User Community.

\section{List of collecting sites}

1) Cottage Erika (Chata Erika), $48^{\circ} 46^{\prime} 51.8^{\prime \prime} \mathrm{N}, 20^{\circ} 58^{\prime} 31.7^{\prime \prime} \mathrm{E}$;

2) Rocks on the northwest slope, $1182 \mathrm{~m}$ a.s.l., $48^{\circ} 46^{\prime} 55.5^{\prime \prime} \mathrm{N}, 20^{\circ} 58^{\prime} 50.9^{\prime \prime} \mathrm{E}$;

3) Meteorological and radar station, $1245 \mathrm{~m}$ a.s.l., $48^{\circ} 46^{\prime} 55.5^{\prime \prime} \mathrm{N}, 20^{\circ} 59^{\prime} 16.6^{\prime \prime} \mathrm{E}$;

4) Rocks on the south side of the radar station, $1236 \mathrm{~m}$ a.s.l., $48^{\circ} 46^{\prime} 54.4^{\prime \prime} \mathrm{N}, 20^{\circ} 59^{\prime} 12.5^{\prime \prime} \mathrm{E}$;

5) Columns of peace, Kojšovská hol'a, 1219 m a.s.l., $48^{\circ} 46^{\prime} 52.4^{\prime \prime} \mathrm{N}, 20^{\circ} 59^{\prime} 10.9^{\prime \prime} \mathrm{E}$;

6) The eastern side of the radar station, $1222 \mathrm{~m}$ a.s.l., $48^{\circ} 46^{\prime} 55.9^{\prime \prime} \mathrm{N}, 20^{\circ} 59^{\prime} 20.2^{\prime \prime} \mathrm{E}$.

Common species recognized in field were marked by "not.". Species typical for habitat were collected and deposited in the herbarium of P. J. Šafárik University in Košice (KO) with registration number (no.). Some microlichen species growing on protected monuments or those with too small population were not collected.

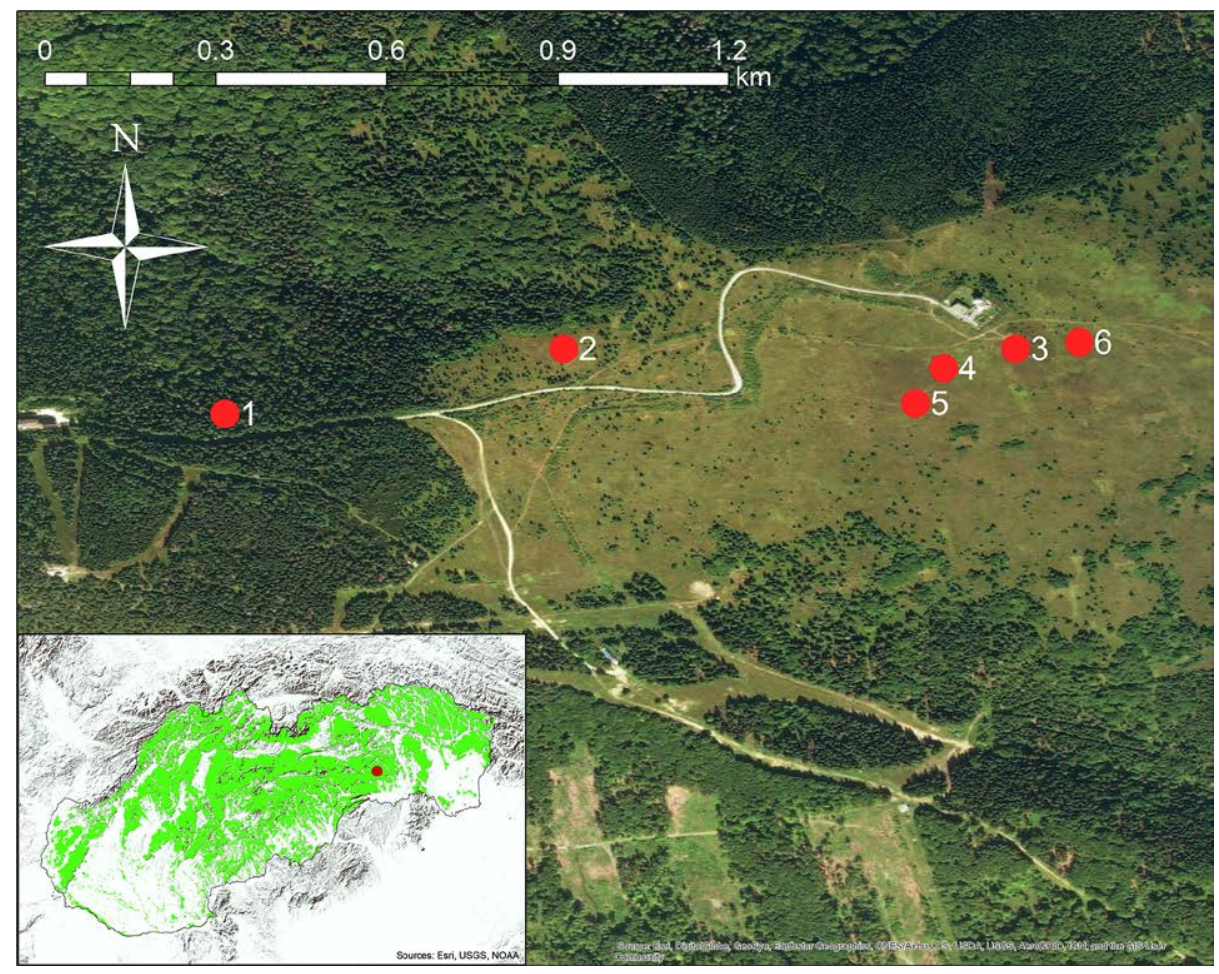

Fig. 1. Map of Kojšovská hol'a with the localities, where lichens were collected 


\section{RESULTS}

During the field research, 35 lichen species were collected, which are listed below in three groups; widespread and very common (C), typical for this habitat (T) and vulnerable (VU) species.

List of recorded (identified) lichens

Acarospora fuscata (Nyl.) Th. Fr. - 2, 3, 4 (C): on siliceous rocks (not.)

Caloplaca holocarpa (Hoffm.) A. E. Wade-3, 4 (C): on limestone rocks (not.)

Candelariella aurella (Hoffm.) Zahlbr. -3 (C): on sunny faces of limestone rocks (not.)

Candelariella vitellina (Hoffm.) Müll. Arg. - 3 (C): on sunny faces of siliceous rocks (not.)

Cetraria ericetorum Opiz - $4(\mathrm{~T})$ : on soil among Calluna vulgaris and Vaccinium vitis-idaea (not.)

Cetraria islandica (L.) Ach. - 2, 4, 5, 6 (T): on soil among Calluna vulgaris and Vaccinium vitis-idaea (no. 33990)

Cladonia chlorophaea (Sommerf.) V. Wirth -2 (C): on soil among grass and outcrops of limestone rock (not.)

Cladonia ciliata var. tenuis Stirton - 6 (VU): on bare soil among grass and Vaccinium vitis-idaea (no. 33991)

Cladonia coniocraea (Flörke) Spreng. -2 (C): on soil among grass and outcrops of limestone rock (not.)

Cladonia cornuta (L.) Hoffm. - 2 (VU): on bare soil among grass and outcrops of limestone rock (not.)

Cladonia fimbriata (L.) Fr. - 2, 5 (C): on soil among grass and outcrops of limestone rock (not.)

Cladonia foliacea (Huds.) Willd. - 2 (C): on soil among grass and outcrops of limestone rock (not.)

Cladonia furcata (Huds.) Schrad. - 2(C): on soil among grass and outcrops of limestone rock (not.)

Cladonia macilenta Hoffm. - 2 (T): on soil among grass and outcrops of limestone rock (no. 33992)

Flavocetraria cucullata (Bellardi) Ach. $-5,6(\mathrm{~T})$ : on soil among grass and Vaccinium vitis-idaea (no. 33993)

Hypogymnia physodes (L.) Nyl. - 1 (C): on bark of Picea abies (not.)

Lecanora albescens (Hoffm.) Branth et Rostr. -4 (C): on limestone rocks (not.)

Lecanora dispersa (Pers.) Sommerf. $-3,4(\mathrm{C})$ : on sunny faces of limestone rocks (not.) 
Lecanora muralis (Schreb.) Rabenh. - 3 (C): on sunny faces of limestone rocks (not.)

Lecanora polytropa (Hoffm.) Rabenh. - 2, 4 (T): on siliceous rocks (not.)

Lecanora rupicola (L.) Zahlbr. - 2 (T): on siliceous rocks (not.)

Lecidella sp. -2 (C): on siliceous rocks (not.)

Lepraria sp. -1 (C): on bark of Pinus sylvestris (not.)

Parmelia omphalodes (L.) Ach. - 2 (T): on siliceous rocks (not.)

Parmelia saxatilis (L.) Ach. -2 (C): on siliceous rocks (not.)

Parmelia sulcata Taylor - 1, 2 (C): on limestone rocks (not.)

Pseudevernia furfuracea (L.) Zopf - 1 (C): on bark of Picea abies (not.)

Rhizocarpon geographicum (L.) DC. $-3,4$ (T): on siliceous rocks (not.)

Rhizocarpon lecanorinum Anders - 4 (T): on siliceous rocks (not.)

Umbilicaria cylindrica (L.) Duby - 4 (T): on vertical surfaces of siliceous rocks (no. 33994)

Umbilicaria deusta (L.) Baumg. - 4 (C): on vertical surfaces of siliceous rocks (not.)

Umbilicaria polyphylla (L.) Baumg. - 4 (C): on vertical surfaces of siliceous rocks (not.)

Umbilicaria vellea (L.) Hoffm. - 4 (VU): on vertical surfaces of siliceous rocks (no. 33995)

Xanthoria elegans (Link) Th. Fr. - 3 (C): on sunny faces of limestone rock (not.) (not.)

Xanthoria parietina (L.) Th. Fr. - 1, 3 (C): on sunny faces of limestone rock

\section{DISCUSSION}

Kojšovská hol'a is covered by grassland areas of approximately 100 hectares. In between the grassland are widespread patches of Calluna vulgaris, Vaccinium vitis-idaea and Vaccinium myrtillus as well. The following tree species are present: Picea abies, Betula pendula, Sorbus sp. and Acer pseudoplatanus.

The data about lichen species from Kojšovská hol'a, one of the highest part of the Volovec Mts are very poor. However, old literature about presence of the lichens are mentioned by e.g. Hazslinszky $(1859,1870,1884)$, from nearby Zlata Idka and lookout Kloptáň. Only one lichen specimen (Cetraria islandica subsp. islandica) from Kojšovská hola is deposited in the Herbarium of Pavol Jozef Šafárik University in Košice, which was collected by M. Dudáš in 2015. Here we present the actual lichen list, which can be still extended. In our list of 35 lichen species there are three, which are interesting, because of their red list status in Slovakia. Lichens below are listed as vulnerable (below abbreviated as VU) in our national red list (Pišút et al. 2001). 
Cladonia ciliata var. tenuis (VU): primary thallus is crustose, rarely seen, even evanescent. Podetia branching, of 5-12 cm tall with $0.5-0.8 \mathrm{~mm}$ thickness and very slender branches. The colour is greenish grey, and bases are not blackening. Tips are often strongly brown. Surface is ecorticate, densely arachnoid. Soredia and squamules are not present. Apothecia are common, small, with brown colour. Typical habitat is coastal heathlands and more rarely in forests (Stenroos et al. 2016).

New locality: Kojšovská hola, the eastern side of the radar station on bare soil among shrubs of Vaccinium vitis-idaea, $1222 \mathrm{~m}$ a.s.l., WGS-84: $48^{\circ} 46^{\prime}$ $55.9^{\prime \prime} \mathrm{N}, 20^{\circ} 59^{\prime} 20.2^{\prime \prime}$ E, 2017.

Other records: Šajdíkové Humence, $1 \mathrm{~km}$ west, in light secondary pine forest (Dicrano-Pinion), $208 \mathrm{~m}$, WGS-84: 48 38' 38.4" N, 17 15' 09.1" E (Dingová and Pišút 2009). - Lakšárska Nová Ves, $2 \mathrm{~km}$ northwest, in light secondary pine forest (Dicrano-Pinion), 219 m, WGS-84: 48 35' 10.4" N, 17 10' 23.9" E (Dingová and Pišút 2009). - Between town Malacky and village Studienka, in a clearing in old production forest, $195 \mathrm{~m}$, WGS-84: $48^{\circ} 29^{\prime} 43.0^{\prime \prime} \mathrm{N}, 17^{\circ} 05^{\prime}$ 56.6" E (Dingová and Pišút 2009). - On impact area of military space, Bežnisko, $4 \mathrm{~km}$ south of Mikulášov in small forest of Pinus sylvestris, $220 \mathrm{~m}$, WGS-84: $48^{\circ}$ 31' 46.4" N, $17^{\circ} 14^{\prime} 46.0^{\prime \prime}$ E (Dingová and Pišút 2009). - Borský Peter, 1.5 km northeast, in light secondary pine forest (Dicrano-Pinion) among bryophytes

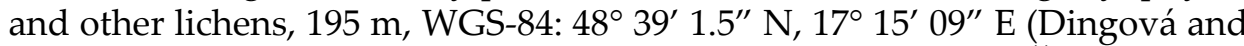
Pišút 2009). - Borská nížina-lowland, general data Suza (1920), Šaštín-Stráže, 170 and 180 m (Pišút 1962, 1964), Mešterova lúka, meadow near gamekeeper's lodge Červený kríž, 190 m (Guttová and Pišút 2007). - Malé Karpaty: Inter Callunas in dec. ad occidentem spectanti in valle Borinské údolie prope pag. Borinka, alt. ca 380 m s. m., 1954 leg. I. Pišút (BRA); ibid. ca 300 m s. m., 1958 leg. I. Pišút (BRA). - Považský Inovec: Marhat, Vozokany (Suza 1936). - Strážovské vrchy: in colle inter pag. Nitrianske Sučany et Nováky, alt. 400 m (Suza 1930); in pascuis supra pagum Horná Poruba, alt. ca 750 m, 1960 leg. I. Pišút (BRA). - Stiavnické vrchy: Vyhne, Kamenné more, 350-400 m (Pišút 1990). - Oravská kotlina: Námestovo, peat bog Klin, 620 m (Pišút 1962). Západné Tatry: Jamník, $800 \mathrm{~m}$, leg. J. Suza 1926 (PRC); supra monticellum in pascuis inter pag. Žiar et Konská, alt. ca 800-850 m s. m. leg. I. Pišút 1957 (BRA). - Vihorlat: general data Hazslinszky (1884 as C. rangiferina v. tenuis).

Cladonia cornuta (VU): primary thallus is squamulose or even evanescent. Podetia are $4-10 \mathrm{~cm}$ tall with $0.5-2 \mathrm{~mm}$ thickness. Sometimes slightly robust, unbranched or occasionally sparsely branched. Colour is brownish green or greenish grey. Surface is smoothly or slightly areolate-corticate in the lower parts. Upper parts are slightly coarsely sorediate. Presence of apothecia is rare and if present they are brown. Typical habitat for Cladonia cornuta is woodland, rock outcrops, rotten wood and peat. 
New localities: Kojšovská hol'a, rocks on the northwest slope, $1182 \mathrm{~m}$ a.s.l., WGS-84: $48^{\circ} 46^{\prime} 55.5^{\prime \prime} \mathrm{N}, 20^{\circ} 58^{\prime} 50.9^{\prime \prime} \mathrm{E}$, on bare soil among grass and outcrops of limestone rock, 1222 m a.s.l., WGS-84: $48^{\circ} 46^{\prime} 55.9^{\prime \prime} \mathrm{N}, 20^{\circ} 59^{\prime} 20.2^{\prime \prime}$ E, 2017.

Other records: Šajdíkové Humence, $1 \mathrm{~km}$ west, in light secondary pine forest (Dicrano-Pinion), 208 m, WGS-84: 48 38' 38.4" N, 17 15' 09.1" E (Dingová and Pišút 2009). - Lakšárska Nová Ves, 2 km northwest, in light secondary pine forest (Dicrano-Pinion), $219 \mathrm{~m}$, WGS-84: 48 35' 24.7' N, $17^{\circ} 09^{\prime} 28.3^{\prime \prime}$ E (Dingová and Pišút 2009). - Between villages Borský Mikuláš and ŠaštínStráže, $1 \mathrm{~km}$ west from Borský Mikuláš in light secondary pine forest (Dicrano-Pinion), (locality does not exist anymore due to expansion of near sand factory), $200 \mathrm{~m}$, WGS-84: $48^{\circ} 37^{\prime} 38.0^{\prime \prime} \mathrm{N}, 17^{\circ} 11^{\prime} 31.2^{\prime \prime} \mathrm{E}$ (Dingová and Pišút 2009). - Borský Peter, $1.5 \mathrm{~km}$ northeast, in light secondary pine forest (Dicrano-Pinion), among bryophytes and other lichens, $195 \mathrm{~m}$, WGS-84: 48 ${ }^{\circ} 39^{\prime}$ 01.54" N, 17 15' 09" E (Dingová and Pišút 2009). - On impact area of military space - Široká, on soil in light forest of Pinus sylvestris, $190 \mathrm{~m}$, WGS-84: $48^{\circ}$ $24^{\prime} 35.9^{\prime \prime} \mathrm{N}, 17^{\circ} 04^{\prime} 40.5^{\prime \prime}$ E (Dingová and Pišút 2009). - Šajdíkové Humence (Orthová and Kanka 2001). - Šaštín-Stráže (Pišút 1968).

Umbilicaria vellea (VU): Thallus is often large reaching size up to $15 \mathrm{~cm}$ diameter, thick and rigid when it is dry. Upper surface is pale grey, rarely with brownish tinge. Lower surface is black, rarely dark brown. Rhizines are abundant, blackish and branched. Soredia and isidia are absent and apothecia are rare. Umbilicaria vellea prefers open habitats, such as steep rock faces and boulders. The presence of lichen Umbilicaria vellea in Slovakia was recorded by Lisická (1980). There are records from Ipel’sko-rimavská brázda, Vtáčnik, Kremnické pohorie, Štiavnické pohorie, Vihorlat, Nízke Tatry, Západné Tatry, Vysoké Tatry and Belianske Tatry. The finding at Kojšovská hola extended the distribution range of this species.

A further more detailed study may increase the list of species known from the area. Also, its comparison with historical collections of the surrounding areas can be a direction of further studies.

Acknowledgements - We are grateful to Anna Guttová and Edit Farkas for help with identification of lichens and valuable comments. Thanks are due to Martin Bačkor for excursion in Kojšovská hol'a and Matej Dudáš who helped with GPS system. This study was supported by KEGA 012UPJŠ-4/2016. 


\section{REFERENCES}

Dingová, A. and Pišút, I. (2009): Doplnky k poznaniu lišajníkov Borskej nížiny (Juhozápadné Slovensko). - Bryonora 44: 28-33.

Futák, J. (1966): Fytogeografické členenie Slovenska. - In: Futák, J. (ed.): Flóra Slovenska I. Vydavatel'stvo SAV, Bratislava, pp. 535-538.

Guttová, A. and Pišút, I. (2007): Lišajníky záhorskej nížiny (JZ Slovensko). - Bryonora 39: $1-12$.

Hazslinszky, F. (1859): Die Kryoblasten der Eperieser Flora. I. Lecanoreen und Lecideen. Vehr. Vereins Naturk. Presburg, 4: 84-95.

Hazslinszky, F. (1870): Adatok Magyarhon zuzmóvirányához. - Math. és Term. tud. Közl. 7: 43-73. (1869)

Hazslinszky, F. (1884): A Magyar Birodalom zuzmó-flórája. - Kir. Magyar Term.tud. Társulat, Budapest, 304 pp.

Lisická, E. (1980): Flechtenfamilie Umbilicariaceae Fée in der Tschechoslowakei. - VEDA, Vydavatel'stvo SAV, Bratislava, pp. 54-59.

Lisická-Jelínková, E. (1974): Lišajník Parmelia incurva (Pers.) Fr. v Slovenskom rudohorí. Biológia (Bratislava) 29: 331-332.

Miklós, L. (ed.) (2002): Atlas krajiny Slovenskej republiky. - Ministerstvo životného prostredia SR, Bratislava, $342 \mathrm{pp}$.

Orthová, V. (2003): Príspevok k poznaniu lišajníkov Volovských vrchov a Čiernej hory. Bull. Slov. bot. spoločn. 25 (Suppl. 9): 77-86.

Orthová, V. and Kanka, R. (2001): Cladonia portentosa (lichenizované askomycéty) opät nájdená na Slovensku. - Bull. Slov. bot. spoločn. 23: 29-32.

Pišút, I. (1962): Doplnky k poznaniu lišajníkov Slovenska II. - Zborn. Slov. Národ. Múz., Prír. Vedy 8: 95-100.

Pišút, I. (1964): Lichenes Slovakiae exsiccate, editi a Museo Nationali Slovaco. - Bratislava, Fasciculus I (no. 1-25).

Pišút, I. (1968): Doplnok k poznaniu lišajníkov Slovenska V. - Zborn. Slov. Národ. Múz., Prír. Vedy 14: 35-39.

Pišút, I. (1990): Nachträge zur Kenntnis der Flechten der Slowakei 12. - Zborn. Slov. Národ. Múz., Prír. Vedy 36: 9-13.

Pišút, I., Guttová, A., Lackovičová, A. and Lisická, E. (2001): Červený zoznam lišajníkov Slovenska (december 2001). - In: Baláž, D., Marhold, K. and Urban, P. (eds): Červený zoznam rastlín a živočíchov Slovenska. Ochrana Prírody 20 (Suppl.), Bratislava, pp. 23-32.

Stenroos, S., Velmala, S., Pykälä, J. and Ahti, T. (eds) (2016): Lichens of Finland. - Norrlinia 30: 1-896. https://doi.org/10.1639/0007-2745-119.4.459

Suza, J. (1920): Zur Flechtenflora der Sandformation des Marchfeldes. - Verh. Naturf. Vereins Brünn 57: 100-106.

Suza, J. (1930): Lichenes Slovakiae III. - Acta Bot. Bohem. 9: 5-33.

Suza, J. (1936): Lišejníky Pieštanska. - Carpatica 1: 275-331.

Suza, J. (1949): Lišejníky Slovenského Rudohoří. - Acta Acad. Sci. Nat. Moravosiles. 21: 1-22.

Vass, D., Began, A., Gross, P., Kahan, Š., Krystek, I., Köhler, E., Lexa, J., Nemčok, J., Růžička, M. and Vaškovský, I. (1988): Regionálne geologické členenie Západných Karpát a severných výbežkov Panónskej panvy na území ČSSR. Mapa 1 : 500 000. - Geol. Úst. D. Štúra, Bratislava. 